\title{
Spatial and temporal variation of benthic fish assemblages during the extreme drought of 1997-98 (EI Niño) in the middle rio Negro, Amazonia, Brazil
}

\author{
Mario J. F. Thomé-Souza* and Ning Labbish Chao**
}

Spatial and temporal variation in the benthic fish composition, species richness, density and biomass were studied in the lower rio Branco and its confluence with the rio Negro during the 1997-98 dry season (September to February). Samples were taken with a $5.28 \mathrm{~m}$ (16-ft) otter trawl in three expeditions and at two depth strata $(<7 \mathrm{~m}$ and $>7 \mathrm{~m})$. Five to seven trawl hauls were made randomly in each sample site per expedition. A total of 58 trawls yielded 134 species, 5,657 individuals and $22 \mathrm{~kg}$ total biomass. Fishes were distributed in 25 families and seven orders. Siluriformes was the most specious with 59 species, followed by Gymnotiformes (30), Characiformes (30), Perciformes (9), Clupeiformes (4), Pleuronectiformes (1) and Tetraodontiformes (1). The variation on composition, richness of species, density and biomass occurred during the dry season, from September 1997 to February 1998. Differences between depth strata were observed. Siluriformes and Gymnotiformes were more abundant at the beginning of the dry season (September) but diminished toward the end of dry season (February), whereas the Perciformes and Characiformes (mainly post-larvae and juveniles) became more abundant at the end of the dry season. The diminishing density of benthic fish communities during this extremely dry season may have been caused by predation or migration.

A variação espacial e temporal da composição da assembléia de peixes bentônicos, assim como a riqueza de espécies, densidade e biomassa foram estudadas ao longo de uma estação de forte seca no baixo rio Branco e na sua confluência com o rio Negro (setembro 1997 a fevereiro 1998). As amostras foram realizadas com uma rede de arrasto de fundo em três expedições ao rio Negro e duas ao rio Branco, a duas profundidades previamente definidas ( $\langle 7 \mathrm{~m}$ e $>7 \mathrm{~m})$. Em cada época e área foram realizados de cinco a sete arrastos em cada estrato de profundidade. Foram realizados no total 58 arrastos capturando 5.657 peixes (22 $\mathrm{Kg}$ ), distribuídos em 25 famílias e 134 espécies. Os Siluriformes foram mais diversos com 59 espécies, seguidos pelos Gymnotiformes (30), Characiformes (30), Perciformes (9), Clupeiformes (4), Pleuronectiformes (1) e Tetraodontiformes (1). As amostras apresentaram mudanças na composição, riqueza de espécies, densidade e biomassa ao longo do período de seca, mas não apresentaram uma clara diferença entre os estratos de profundidade a não ser a composição e riqueza de espécies que foi diferente entre os estratos estudados. As ordens Siluriformes e Gymnotiformes, que foram as mais abundantes no início das coletas, apresentaram forte redução nas suas populações ao longo desse período. Já os Perciformes e Characiformes aumentaram suas densidade e tornaram-se os mais abundantes no final da seca, sendo representados, principalmente, por pós-larvas e juvenis. Foi sugerido que a principal causa da redução na comunidade de peixes bentônicos pode ter sido por predação ou migração.

Key words: Main channel river, Otter trawl, rio Branco, El-Niño phenomenon.

\section{Introduction}

Studies in deep channels of neotropical rivers using otter trawls have shown that benthic fish assemblages are composed predominantly of Siluriformes and Gymnotiformes (Steinbach, 1970; Lopez-Rojas et al., 1984; Lundberg et al., 1987; Chao,
2001). Ecological studies made by Barletta (1995) and CoxFernandes (1995) observed a high abundance of benthic fish in the first ten meters of depth in the main channel, which correlated with a general decrease in species richness and abundance in deeper waters.

Variation in fish captures during the hydrological cycle

\footnotetext{
*Laboratório de Zoologia, Centro Universitário Nilton Lins. Av. Prof. Nilton Lins, 3259, Parque das Laranjeiras. 69.058-040 Manaus, AM, Brazil. e-mail: thome@inpa.gov.br

*,**Laboratório de Ictiologia, Departamento de Ciências Pesqueiras, Universidade Federal do Amazonas (UFAM). Av. Gal. Rodrigo Octávio Jordão Ramos, 3000. 69077-000 Manaus, AM, Brazil. e-mail: piabas@aol.com
} 
has also been observed (Barletta, 1995; Garcia, 1995). During flood periods, these last authors collected fewer individuals per unit effort than during dry periods. The hypothesis proposed that with flooding of marginal areas, benthic fish migrated laterally into the floodplain to refuge opportunities. In comparison, when the water recedes during the dry periods there is a large concentration of benthic fish in the deeper channels, resulting in greater fish densities.

These findings contrast markedly with the assemblages of fish that inhabit the marginal areas of the floodplain, where Characiformes prevail (Goulding, 1980, Goulding et al., 1988; Bayley, 1983; Junk et al., 1983; Lowe-McConnell, 1987; Winemiller, 1996; Chao, 2001). Communities of fish in the marginal areas of floodplain systems have demonstrated high mortalities during dry periods and greater biomass during flood periods, due to the respective retraction and expansion of aquatic habitat on the floodplain (Lowe-McConnel, 1964; Goulding, 1980; Junk et al., 1983; Winemiller, 1996).

The effects of retraction and expansion of aquatic habitat on benthic fish assemblages in main channel habitats are unknown. The specific objective of this study was to examine the effects of retraction of main channel habitat during an extremely dry period on the temporal and spatial abundance, species richness and composition of benthic

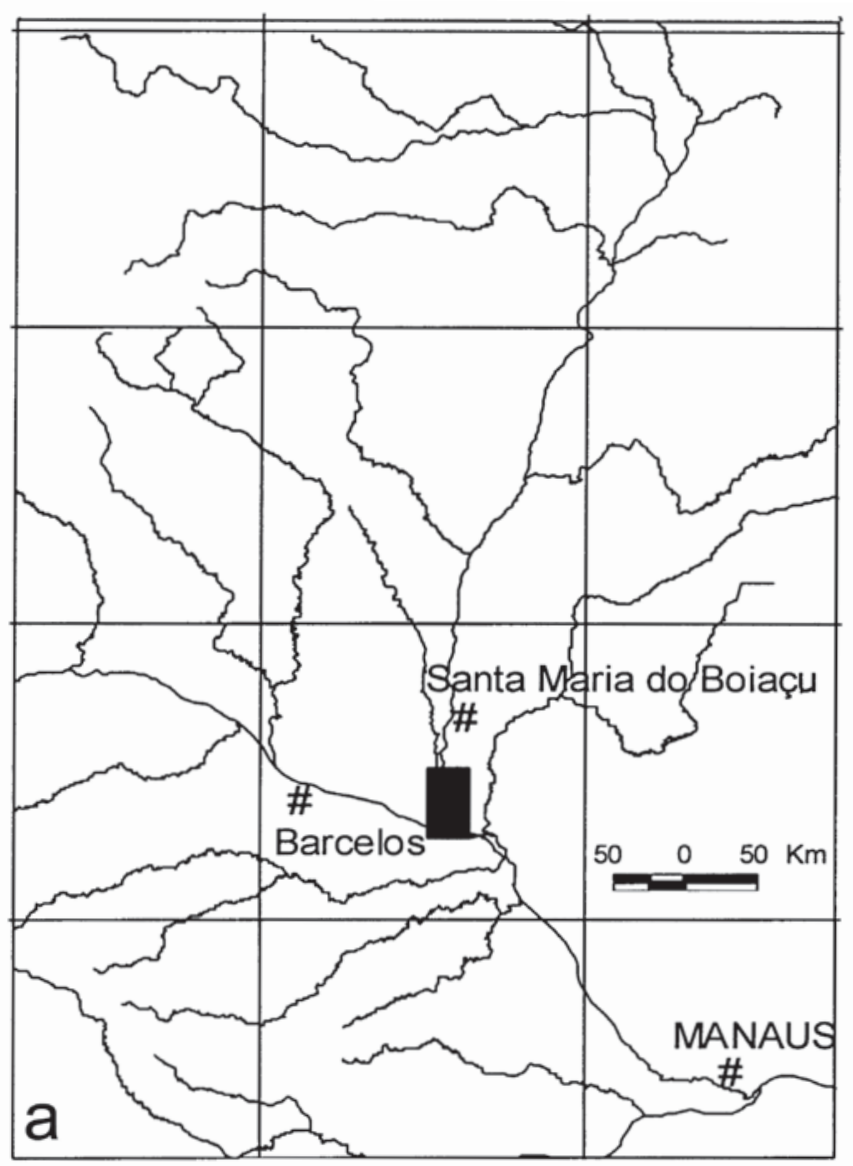

Fig. 1. Study area in middle rio Negro basin (a) and detail of the sampling sites (b). fish assemblages in two neotropical rivers. The study period coincided with one of the most intense El Niño phenomena ever recorded (1997-98). In the Amazon, El Niño reduces the frequency of precipitation and prolongs the dry period, which reduces the size and volume of water bodies on the floodplain. The drought (1997-98) reduced the river level by two meters and prolonged the dry season three months longer than normal years.

\section{Methods and Materials}

Study area. Research was conducted in two main channel areas in the rio Negro basin. One sampling area was located on the lower rio Branco, approximately $35 \mathrm{~km}$ above its confluence with the rio Negro ( $\left.1^{\circ} 03^{\prime} \mathrm{S} / 61^{\circ} 51^{\prime} \mathrm{W}\right)$ (Fig. 1). The other was on the rio Negro in the confluence zone with the rio Branco ( $\left.1^{\circ} 24^{\prime} \mathrm{S} / 61^{\circ} 50^{\prime} \mathrm{W}\right)$. In this research, we restricted our classification of channel area to the bed of the river channel, while the marginal areas were referred to as the zones adjacent to the channel that are inundated annually. River level data (Fig. 2) was provided by the Compania de Pesquisas em Recursos Minerais (CPRM), and was collected in the towns of Santa Maria do Boiaçu ( $00^{\circ} 33^{\prime}$ S / 61 $48^{\circ} \mathrm{W}$ ) on the rio Branco and Barcelos $\left(00^{\circ} 58^{\prime}\right.$ 'S / $\left.62^{\circ} 56^{\prime} \mathrm{W}\right)$ on the rio Negro.

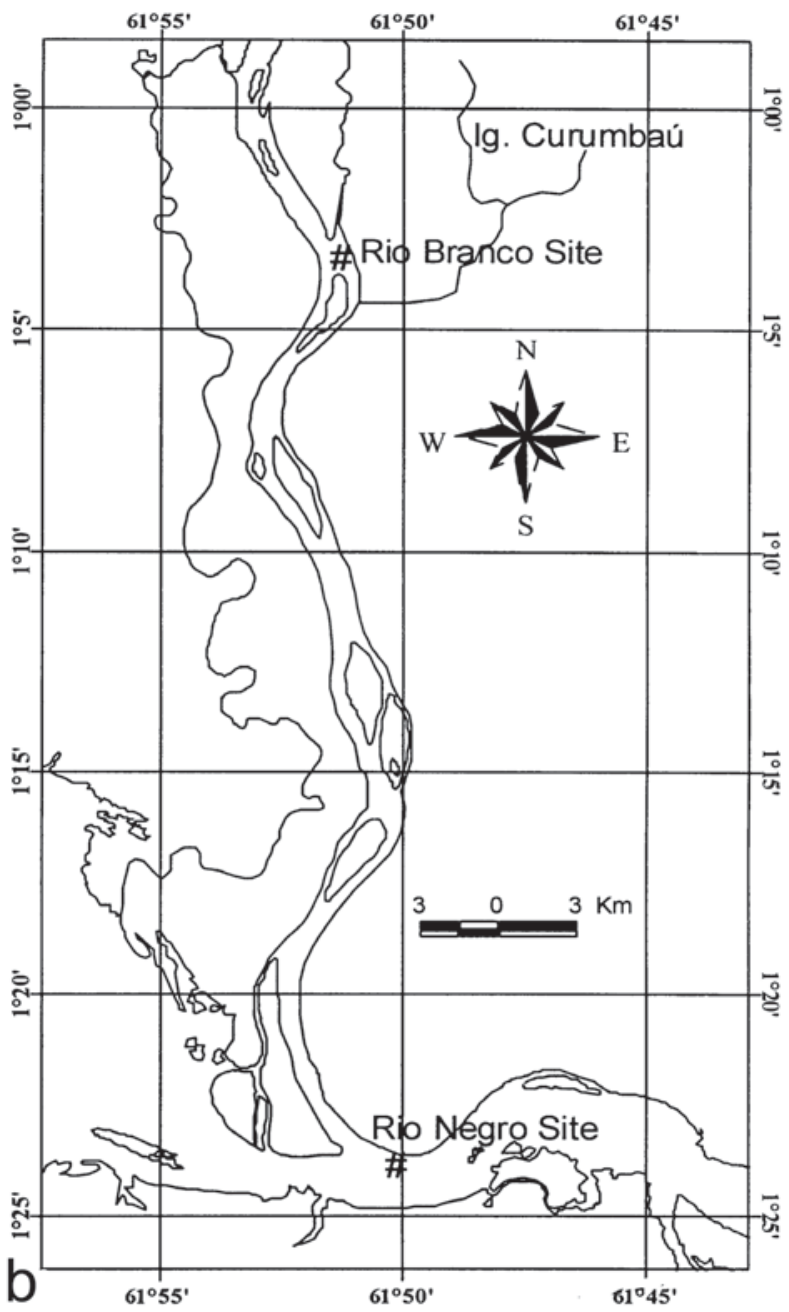




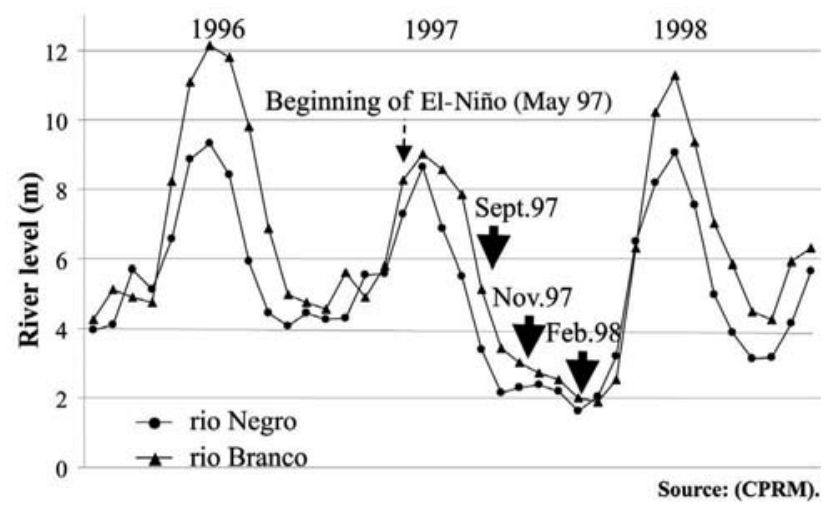

Fig. 2. River level during annual flood cycles. Large arrows denote dates of sampling expeditions.

Sampling methodology. Sampling expeditions were made between September 1997 and February 1998, during the period of intense drought caused by the El Niño of 1997-98 (INPE, 1997). Two expeditions were made to the rio Branco (September 1997 and February 1998) and three to the rio Negro (September and November 1997 and February 1998) (Fig. 2). Samples were collected using a $5.28 \mathrm{~m}$ otter trawl with $35 \mathrm{~mm}$ mesh on the body, $25 \mathrm{~mm}$ in the sack and $5 \mathrm{~mm}$ in the cod-end liner. The trawl was pulled by an $8 \mathrm{~m}$ wooden canoe, with a 40 HP outboard motor. Trawl duration was 10 minutes each and was made in the direction of the current. The speed of the canoe was maintained at approximately $6 \mathrm{~km} \cdot \mathrm{h}^{-1}$, and was monitored by GPS. Depth was measured and controlled using a portable eco-sounder. Samples were collected randomly along a stretch of $10 \mathrm{~km}$ upstream and $10 \mathrm{~km}$ downstream from the geo-referenced point in each study area.

In each collection expedition, trawls were made at two strata depths $(<7 \mathrm{~m}$ and $>7 \mathrm{~m})$. Depth strata were defined as such because maximum depth of the study area in the rio Branco during the drought was less than $15 \mathrm{~m}$, while at the study area in the rio Negro the maximum depth may reach $35 \mathrm{~m}$. Five to seven trawls at each depth were made (variation was due to the difficulty in finding the desired strata depths). After each trawl, the collected fish were preserved in $10 \%$ formalin solution and were then identified, counted, weighed (g) and measured for standard length (SL, cm). Fishes were later preserved in 70\% alcohol and deposited in the fish collections at INPA (Instituto Nacional de Pesquisas da Amazônia) and UFAM (Universidade Federal do Amazonas).

During the trawl operations, we measured water temperature $\left({ }^{\circ} \mathrm{C}\right)$, dissolved oxygen concentration $\left(\mathrm{mg} .1^{-1}\right), \mathrm{pH}$, and conductivity $\left(\mu \mathrm{S} . \mathrm{cm}^{-1}\right)$. These measurements were made at the surface and at the bottom of the channel. For the bottom sample, a Van Dorn bottle was used. Water transparency was measured with a Secchi disk $(\mathrm{cm})$.

Statistical analyses. Benthic fish abundance data from each study area were expressed as CPUA (catch per unit area) index (Sparre et al., 1995), for the analysis of variations over time (months) and spatial depth (strata) of the number of individuals and biomass captured. Biomass and density of the captured species were calculated and expressed in $\left(\mathrm{g} . \mathrm{m}^{-2}\right)$ and (ind. $\mathrm{m}^{-2}$ ), respectively. To facilitate the presentation of the results the values of these estimates were multiplied by $10^{3}$. Density and biomass were compared between months and strata using Kruskal-Wallis (H test) and Mann-Whitney (U test), for three and two categorical levels, respectively (Zar, 1984). Species richness was compared between months and strata depths for each area using the rarefaction method [E(Sn)] proposed by Sanders (1968).

To analyze the structure composition of benthic fish assemblages, the data from the two areas were investigated in relation to time (months), river site (Branco or Negro) and depth (strata). Hybrid Multidimensional Scaling (HMDS), a hybrid of MDS, was used to ordinate the data in two dimensions, using Pattern Analysis Package (PATN) (Beldin, 1995). The dissimilarity matrix entered in the ordination was based on the absolute frequency individuals data of species captured using the Bray-Curtis index. Data were ordinated into objects (species) and attributes (river sites, months and depths). Data were not transformed due to our principal objective of demonstrating patterns based on common fish species, which tended to exhibit large differences in abundance attributes. The combination of applying the Bray-Curtis dissimilarity index with this type of ordination is an efficient way to demonstrate ecological gradients based on the abundance data of species (Faith et al., 1978). To test the relationship between species composition and the independent variables for the two dimensions of HMDS, multivariate analyses of covariance (MANCOVA) was used. The Pillai trace test was applied because it is the most robust for defending violations of assumptions (Olson, 1976).
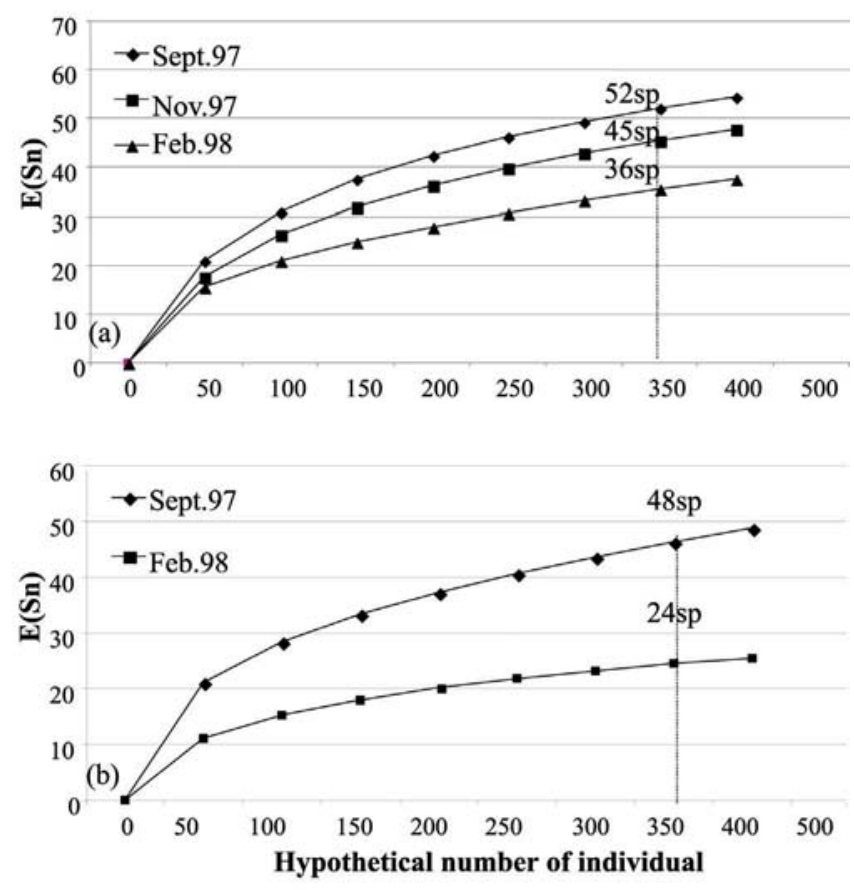

Fig. 3. Estimated species richness $E(\mathrm{Sn})$ by months of collection for (a) rio Negro and (b) rio Branco. 


\section{Results}

A total of 5,657 fish ( $22 \mathrm{~kg}$ ) from 25 families and 134 species were collected. Siluriformes were the most diverse with 59 species, followed by Gymnotiformes (30), Characiformes (30), Perciformes (9), Clupeiformes (4), Pleuronectiformes (1) and Tetraodontiformes (1) (Table 1). Hydrographic parameters (pH, conductivity and temperature) tended to be different between rivers. Temporal variations in density and biomass were observed for the rio Negro site, as well as temporal variations in species richness for both the Negro and Branco sites. Variations in species richness and abundance did not differ between strata depths, with the exception of species richness at the rio Negro site in September 1997 and February 1998 at the rio Branco site. Structure composition of the benthic fish assemblages showed variation between months, rivers and strata depths.

Hydrographic parameters. The mean values of hydrographic parameters at the rio Negro site tended to be lower than at the rio Branco site; $\mathrm{pH}$ (5.8 and 6.5), conductivity (5.7 and 9.0 $\mathrm{mS.cm}-1)$ and temperature $\left(31\right.$ and $\left.32{ }^{\circ} \mathrm{C}\right)$, respectively. Dissolved oxygen tended to be higher at both sites near the surface (5.4 to $7.0 \mathrm{mg} . \mathrm{l}^{-1}$ ) and lower at the bottom of the channel (2.6 to $6.4 \mathrm{mg} . \mathrm{l}^{-1}$ ). Water transparency varied from 0.4 to $1.2 \mathrm{~m}$ at both sites.

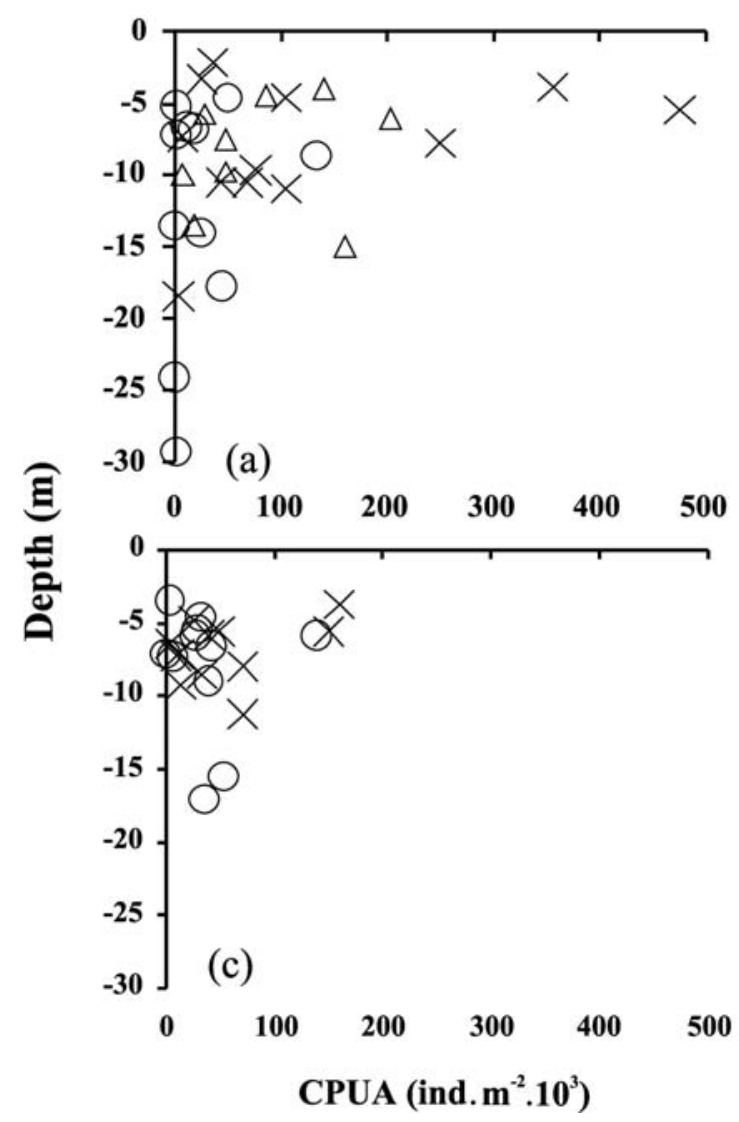

Temporal and spatial variations of benthic fish. At the rio Negro site, collections made at the beginning of the drought (September 1997) yielded the highest species richness, with 52 species in a sample of 350 individuals (Fig. 3a). In the middle of the drought (November 1997) the same site yielded 45 species, and in February 1998 there were only 36 species in a sample of 350 individuals. The number of individuals and the biomass (Figs. 4a-b) of the catch reduced progressively and significantly during the period of drought, Kruskal-Wallis $(\mathrm{H}=8.48 ; \mathrm{df}=2 ; P=0.01)$ and $(\mathrm{H}=8.46 ; \mathrm{df}=2 ; P=0.01)$, respectively. The a posteriori test of multiple non-parametric comparison for numbers of individuals and biomass indicated that the samples in September 1997 were significantly higher than samples in February $1998(P<0.05)$. The density of the fish catch in the samples went from 100 (ind. $\mathrm{m}^{-2} .10^{3}$ ) in September 1997 to 69 in November to 24 in February 1998 (Table 1). The CPUA values of biomass decreased from 395 (g. $\mathrm{m}^{-2} .10^{3}$ ) to 235 to 120 for the same respective months.

At the rio Branco site, the collection made at the beginning of the drought also presented higher species richness, with 48 species in a sample of 350 individuals, compared to 24 species caught in February (Fig. 3b). Differences between CPUA values of the number of individuals and biomass (Figs. 4c-d) from September 1997 to February 1998 were not significant, MannWhitney $\left(\mathrm{U}=77 ; \chi^{2}=0.45 ; \mathrm{df}=1 ; P=0.48\right)$ and $\left(\mathrm{U}=68 ; \chi^{2}=\right.$
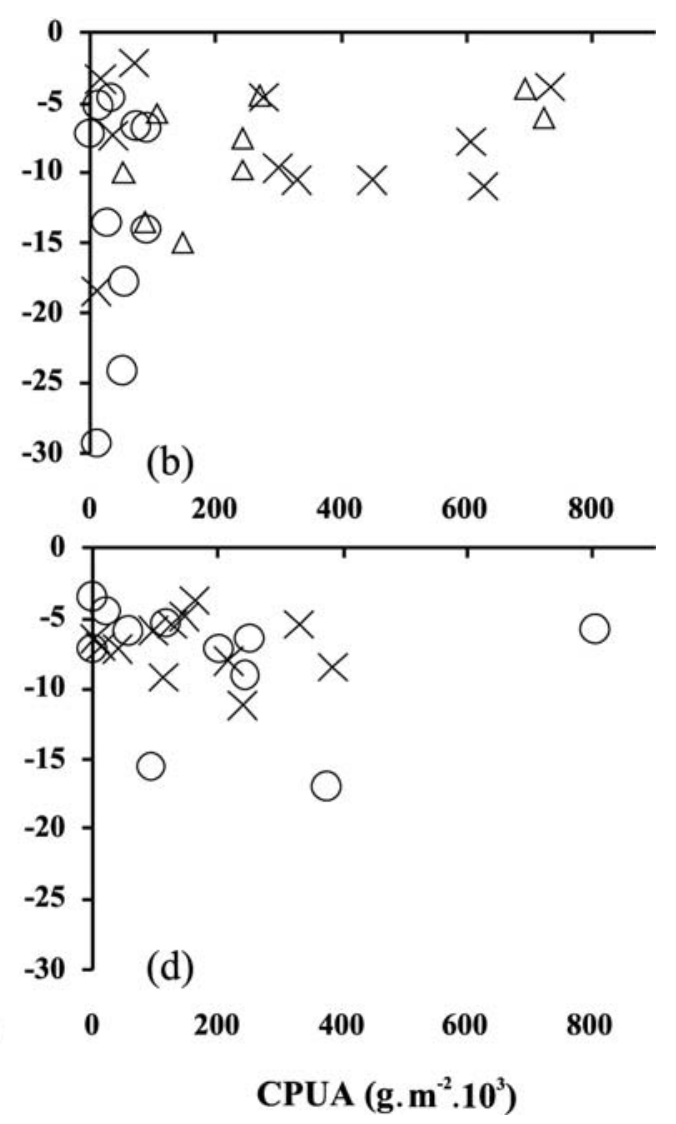

Fig. 4. Temporal and spatial variation of CPUA in number of individuals (ind. $\mathrm{m}^{-2} \cdot 10^{3}-\mathrm{a}$ and $\mathrm{c}$ ) and biomass $\left(\mathrm{g} \cdot \mathrm{m}^{-2} \cdot 10^{3}-\mathrm{b}\right.$ and d) captured on the rio Negro (a and b) and rio Branco (c and d) for each trawl in: $\left(^{\times}\right)$Sep; $\left({ }^{\triangle}\right.$ ) Nov (just in rio Negro) 1997 and (O) Feb 1998. 
$0.01 ; \mathrm{df}=1 ; P=0.90)$, respectively. The density of the catch at the rio Branco site was 38 and 52 (ind. $\mathrm{m}^{-2} .10^{3}$ ) in September 1997 and February 1998, respectively, and the biomass was 204 and $150\left(\mathrm{~g} . \mathrm{m}^{-2} .10^{3}\right)$, respectively (Table 1$)$.

At both sites there were no significant differences in species richness between strata depths. However, there were a few exceptions. At the rio Negro site in September 1997, 37 species were collected at the deepest strata $(>7 \mathrm{~m})$, as opposed to 28 species collected from the shallowest strata $(<7 \mathrm{~m})$ in one sample of 170 individuals (Fig. 5a). At the rio Branco site, 21 and 14 species, respectively, were collected for the same size sample in February 1998 (Fig. 5e). Effects of density and biomass on depth strata were not significant in both study areas. At the rio Negro site, Mann-Whitney $\left(\mathrm{U}=160.5 ; \chi^{2}=\right.$ $1.55 ; \mathrm{df}=1 ; P=0.21)$ for density and $\left(\mathrm{U}=123: \chi^{2}=0.20 ; \mathrm{df}=1\right.$; $P=0.64$ ) for biomass (Figs. 4a-b). At the rio Branco, MannWhitney $\left(\mathrm{U}=71 ; \chi^{2}=0.13 ; \mathrm{df}=1 ; P=0.71\right)$ for density and $(\mathrm{U}$ $=51 ; \chi^{2}=0.75 ; \mathrm{df}=1 ; P=0.38$ ) for biomass (Figs. $4 \mathrm{c}-\mathrm{d}$ ).

The ordinations of benthic fish specie composition showed significant differences between the collections of February 1998 (Fig. 6a) and the collections of September and November of 1997, MANCOVA (Pillai Trace $=0.358, F 4,100=5.445, P=$ 0.01 ) and with respect to rivers (Fig. 6b), MANCOVA (Pillai Trace $\left.=0.274, F_{2,49}=9.257, P=0.01\right)$ and depth (Fig. 6c), MANCOVA (Pillai Trace $=0.446, F_{2,49}=19.728, P=0.000$ ).

\section{Discussion}

The direct and indirect impacts of drought can greatly reduce population densities, species richness and alter lifehistory cycles, species composition, type and strength of biotic interactions (predation and competition), food resources, trophic structure and ecosystem processes (Lake, 2003).

During the drought period of 1997-98, samples of benthic fish communities at rio Branco and rio Negro study sites have shown seasonal reductions in the number of individuals, biomass and species richness, as well as spatial variations. However, $\mathrm{U}$ test application failed to detect a significant difference in abundance between samples at the rio Branco site. This is probably due to the low sensitivity of the index used for detecting the differences of number and weight of fishes caught. For example, the 38 species captured at the end of the drought (February, 1998) at the rio Branco site, five species (Creagrutus cf. cochui Géry, Anchovia surinamensis (Bleeker), Geophagus sp. (new), Pimelodus altipinnins Steindachner and Pachyurus schomburgkii Günther) accounted for $83 \%$ of the total individuals captured, mostly post-larval and juvenile specimens. In turn, the total increases of these five species, minus reproductions and recruitments, masked the real reduction of the benthic fish community as a whole. A significant reduction of population density was found (Mann-Whitney, $P=0.01$ ) after removing these five species from the data set.

Changes in the compositions of the benthic fish community at the end of the drought in February 1998 correlated with the reductions in abundance over the course of the collections at
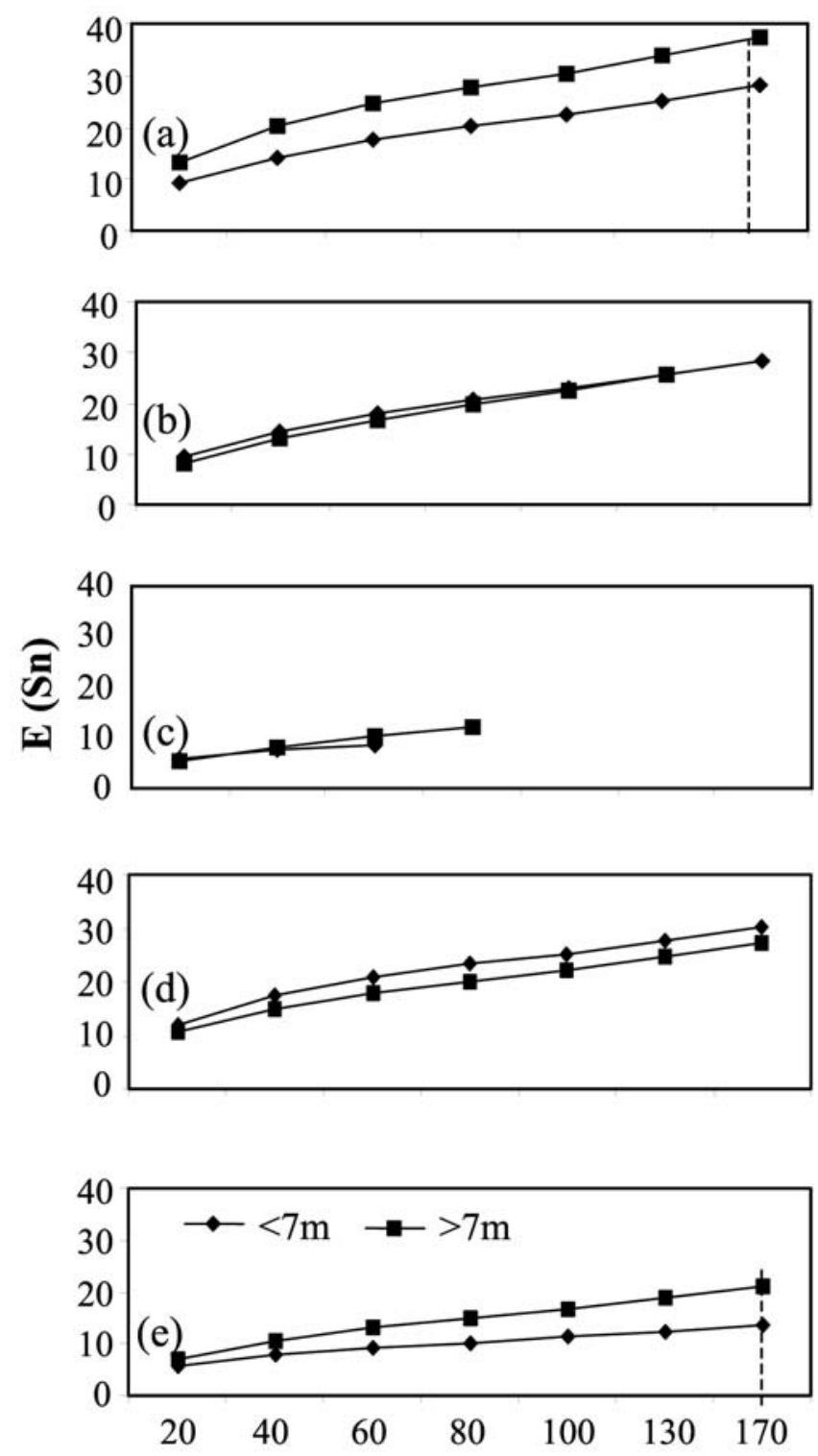

Fig. 5. Estimated species richness $\mathrm{E}(\mathrm{Sn})$ by strata at rio Negro (a-Sep, b-Nov 1997 and c-Feb 1998) and rio Branco (d-Sep 1997 and e-Feb 1998).

the two river sites. Previous studies have found that Silurifomes and Gymnotiformes are the most abundant groups of benthic fish in neotropical river channels (Lopez-Rojas et al., 1984; Lundberg et al., 1987; Chao, 2001). However, by the end of the drought these two groups had practically disappeared from our trawl samples. Silurifomes and Gymnotiformes were replaced by smaller species of Characiformes and Perciformes, which were predominantly represented at both sites by postlarval and juvenile stages of two species: Creagrutus cf. cochui and Geophagus sp. (new).

Due to a large reduction in available aquatic habitat during the dry season, few species are able to thrive in low water periods (Magoulick \& Kobza (2003). However, Winemiller \& Jepsen (1998) observed that a characin, Roebides dayi (Steindachner), and a cichlid, Caquetaia kraussii (Steindachner), 

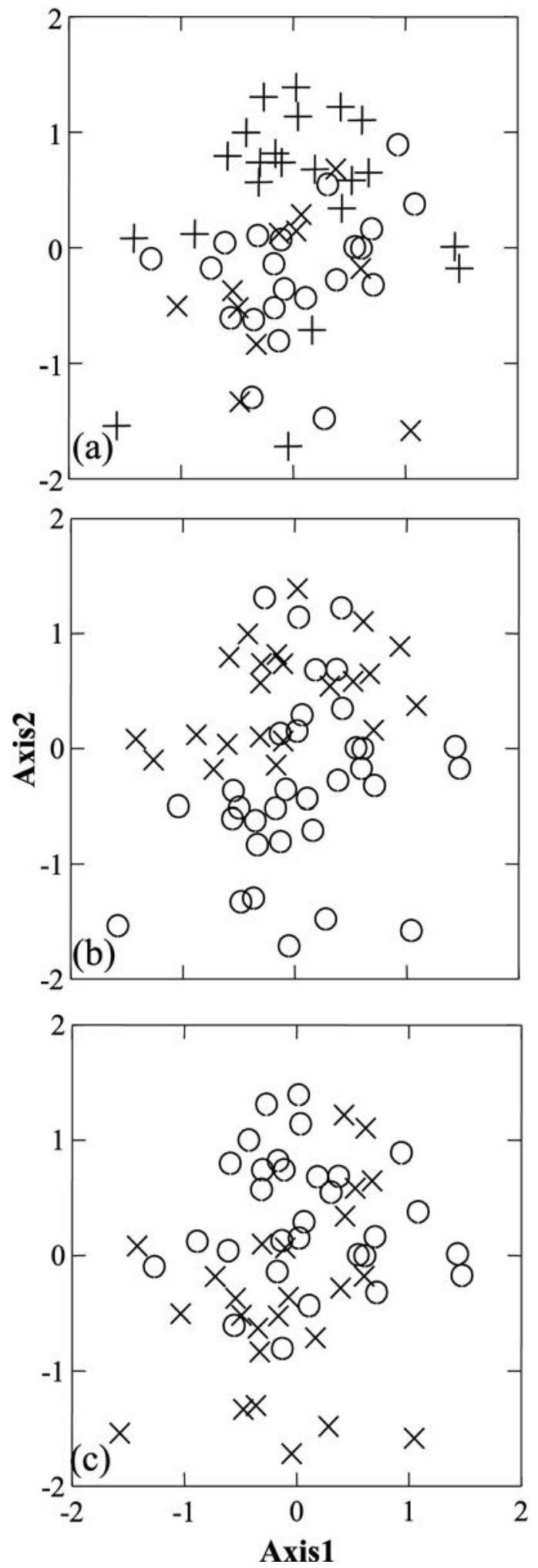

Fig. 6. Hybrid multidimensional scaling (HMDS) ordination plot in two dimensions of benthic fish assemblage composition between Month ( $\mathrm{a} ; \mathrm{O}-\mathrm{Sep}, \times-\mathrm{Nov},+-\mathrm{Feb})$, River (b; O-rio Negro, $\times$-rio Branco) and Depth (c; $\mathrm{O}-<7 \mathrm{~m}, \times->7 \mathrm{~m}$ ). This ordination explained $\sim 39 \%$ of the variance in the association matrix $\left(r^{2}=0,384\right)$. were successfully reproduced during low water periods in small bodies of water in the Venezuelan Llanos. We believe that the increases in abundance of Creagrutus cf. cochui and Geophagus sp. (new) were due to increases in beach habitat during the low water period, as they were encountered in depths less than 3 m. Magoulick \& Kobza (2003) argued that large fish are not able to survive in extreme shallow water; however, smaller fish might be able to take advantage of such conditions though avoidance of aquatic predation.

The difference of species composition among sites was detected. The rio Branco trawl samples showed lower diversity of Silurifomes and Gymnotiformes than that of the rio Negro in September 1997. This may indicate that the effects of the drought were already having an effect on the benthic fish populations of the rio Branco, before our study began. We believe that the effects of El-Niño on the rio Branco may have started as early as May of 1997. The peak water level of rio Branco recorded in June of 1997 was three meters below the peak water level in June of 1996 (Fig. 2).

Sioli (1991) stated that rio Branco transports turbid water washed down from up streams during the rainy period; water becomes more transparent in the dry season. The overall lower water level registered in 1997 may prolong the period of drought with greater water transparency, this may increase the pressure of predation on benthic fishes. It is also possible that during the low water period, large numbers of benthic fishes from the rio Branco have migrated to the rio Negro, where the main channel is much deeper.

The migratory behavior of benthic fish populations may be support by trawl samples made in the same sites, during a normal water cycle of 1996 (Chao, 2001). At the same rio Branco site, trawl samples made in November 1996 have shown a similar benthic fish community composition with what was observed at the rio Negro site in September 1997, however, the rio Negro samples in November 1996 had much lower species diversity (23 species) in contrast to 122 species found in 1997. This suggests that the rio Branco benthic fishes, in searching for refuge opportunities, could have migrated to the main channel of the rio Negro during the extreme low water condition of an $\mathrm{El}$ Niño year. The deeper channels and the darker color of the rio Negro water could have provided a refuge for benthic fishes to avoid predation. However, the reduction and change of the benthic fish community in both areas continued throughout the course of the collections sampling.

The Amazon basin has a great number of fish predators that permanently inhabit river channels, or move there seasonally during dry periods (Lowe-McConnell, 1987). Bullock et al. (1979) suggested that Gymnotiformes represent a substantial part of the available biomass for higher levels of the food chain. Zuanon (1990) reported that the large catfish predators of the Amazon River, such as Brachyplatystoma filamentosum (Lichtenstein) and B. flavicans (Castelnau), consume Siluriformes and Gymnotiformes mainly during the falling water and dry periods when the preys are more concentrated in the main channel. At the confluence of the rio Branco with the rio Negro, there is a specific fishery of 
Table 1. Fish caught in channel habitats of the rio Negro and rio Branco (September and November 1997 and February 1998). Each species is represented by number of individuals $(\mathrm{N})$, percent of total catch (\%), density (D - ind. $\left.\mathrm{m}^{2} .10^{3}\right)$, biomass $\left(\mathrm{g} \cdot \mathrm{m}^{2} .10^{3}\right)$ and frequency of occurrence in trawls $(\mathrm{F})$. Values $<1.0$ are represented by $(+)$.

\begin{tabular}{|c|c|c|c|c|c|c|c|c|c|c|c|c|c|c|c|c|c|c|c|c|c|c|c|c|c|}
\hline & \multicolumn{15}{|c|}{ rio Negro } & \multicolumn{10}{|c|}{ rio Branco } \\
\hline & & & Sep & & & & & Nov & & & & & Feb & & & & & Sep & & & & & Feb & & \\
\hline & $\mathrm{N}$ & $\%$ & $\mathrm{D}$ & Bio & $\mathrm{F}$ & $\mathrm{N}$ & $\%$ & D & Bio & $\mathrm{F}$ & $\mathrm{N}$ & $\%$ & D & Bio & $\mathrm{F}$ & $\mathrm{N}$ & $\%$ & D & Bio & $\mathrm{F}$ & $\mathrm{N}$ & $\%$ & $\mathrm{D}$ & Bio & $\mathrm{F}$ \\
\hline Clupeidae & & & & & & & & & & & & & & & & & & & & & & & & & \\
\hline $\begin{array}{l}\text { Ilisha amazonica } \\
\text { Engraulidae }\end{array}$ & & & & & & & & & & & & & & & & & & & & & 1 & + & + & 1.5 & 1 \\
\hline Anchovia sp. & 17 & + & + & 3.3 & 2 & 30 & 2.3 & 1.6 & 1.5 & 3 & 13 & 2.5 & + & + & 1 & 3 & + & + & + & 1 & 184 & 16 & 8.3 & 1.2 & 3 \\
\hline $\begin{array}{l}\text { Lycengraulis sp. } \\
\text { Pristigasteridae }\end{array}$ & 1 & + & + & + & 1 & 10 & + & + & + & 3 & 44 & 8.3 & 2 & + & 3 & 2 & + & + & + & 1 & & & & & \\
\hline $\begin{array}{l}\text { Pristigaster cayana } \\
\text { Hemiodontidae }\end{array}$ & 129 & 6.4 & 6.4 & + & 2 & & & & & & & & & & & 5 & + & + & + & 2 & 6 & + & + & 4.3 & 1 \\
\hline $\begin{array}{l}\text { Hemodontidae } \\
\text { Argonectes longiceps }\end{array}$ & & & & & & & & & & & & & & & & 1 & + & + & + & 1 & & & & & \\
\hline $\begin{array}{l}\text { Hemiodus cf. ternetzi } \\
\text { Hemiodus immaculatus } \\
\text { Curimatidae }\end{array}$ & 1 & + & + & 2.5 & 1 & 1 & + & + & 2.3 & 1 & & & & & & & & & & & & & & & \\
\hline Curimata incompta & 20 & 1 & 1 & 3 & 3 & 1 & + & + & + & 1 & & & & & & 13 & 1.9 & + & 4.5 & 1 & 2 & + & + & 1.8 & 1 \\
\hline Curimata vittata & 11 & + & + & + & 3 & 1 & + & + & + & 1 & & & & & & & & & & & & & & & \\
\hline Curimatella meyeri & 1 & + & + & + & 1 & 1 & + & + & + & 1 & & & & & & 23 & 3.3 & 1.3 & 8.2 & 1 & 4 & + & + & 2 & 2 \\
\hline $\begin{array}{l}\text { Steindachnerina planiventris } \\
\text { Anostomidae }\end{array}$ & 2 & + & + & + & 1 & 2 & + & + & + & 1 & & & & & & 1 & + & + & + & 1 & & & & & \\
\hline Anostomoides laticeps & & & & & & & & & & & & & & & & 1 & + & + & 8.3 & 1 & & & & & \\
\hline Anostomoides $\mathrm{sp} . \mathrm{n}$ & 1 & + & + & + & 1 & & & & & & & & & & & & & & & & & & & & \\
\hline Caenotropus labyrinthicus & 3 & + & + & + & 2 & & & & & & & & & & & 4 & + & + & + & 2 & & & & & \\
\hline Laemolyta varia & 1 & + & + & + & 1 & & & & & & & & & & & & & & & & & & & & \\
\hline Leporinus fasciatus & 2 & + & + & + & 2 & & & & & & & & & & & & & & & & & & & & \\
\hline $\begin{array}{l}\text { Rhytiodus argenteofuscus } \\
\text { Characidae }\end{array}$ & & & & & & & & & & & & & & & & & & & & & 3 & + & + & 20 & 2 \\
\hline Acestrocephalus cf. sardina & 1 & + & + & + & 1 & & & & & & & & & & & 1 & + & + & + & 1 & & & & & \\
\hline Characidae sp. 2 & 30 & 1.5 & 1.5 & + & 6 & 20 & 1.5 & 1.1 & + & 5 & 26 & 4.9 & 1.2 & + & 3 & 36 & 5.2 & 2 & + & 6 & 9 & + & + & + & 1 \\
\hline Characidae sp. 6 & 2 & + & + & + & 2 & 1 & + & + & + & 1 & & & & & & 1 & + & + & + & 1 & & & & & \\
\hline Characidae sp. 8 & & & & & & 1 & + & + & + & 1 & & & & & & 5 & + & + & + & 1 & & & & & \\
\hline Creagrutus cf. cochui & 1 & + & + & + & 1 & 11 & + & + & + & 4 & 85 & 16 & 3.9 & + & 3 & 6 & + & + & + & 3 & 494 & 44 & 23 & 5.2 & 8 \\
\hline Jupiaba scologaster & 12 & + & + & + & 4 & 1 & + & + & + & 1 & & & & & & 76 & 11 & 4.1 & + & 8 & 6 & + & + & + & 3 \\
\hline Lonchogenys ilisha & 2 & + & + & + & 1 & 1 & + & + & + & 1 & & & & & & & & & & & 2 & + & + & + & 1 \\
\hline Microschemobrycon callops & 104 & 5.2 & 5.2 & + & 4 & 19 & + & + & + & 4 & 11 & 2.1 & + & + & 1 & 16 & 2.2 & + & + & 5 & 10 & + & + & + & 5 \\
\hline icroschemobrycon casiquiare & 45 & 2.2 & 2.2 & + & 4 & 4 & + & + & + & 1 & 14 & 2.7 & + & + & 2 & 9 & 1.3 & + & + & 3 & 3 & + & + & + & 2 \\
\hline Microschemobrycon sp. & 1 & + & + & + & 1 & & & & & & & & & & & 2 & + & + & + & 2 & & & & & \\
\hline Roeboides dayi & 30 & 1.5 & 1.5 & 1.1 & 2 & 5 & + & + & + & 2 & 2 & + & + & + & 1 & 1 & + & + & + & 1 & 5 & + & + & + & 1 \\
\hline Serrasalmus sp. 1 (juvenis) & 1 & + & + & + & 1 & & & & & & 2 & + & + & + & 1 & 1 & + & + & + & 1 & & & & & \\
\hline Serrasalmus sp. 2 (juvenis) & 2 & + & + & 1.2 & 2 & & & & & & & & & & & & & & & & & & & & \\
\hline Serrasalmus sp. 3 (juvenis) & & & & & & & & & & & & & & & & & & & & & 1 & + & + & + & 1 \\
\hline Tetragonopterus chalceus & 2 & + & + & + & 2 & & & & & & & & & & & & & & & & & & & & \\
\hline Cynodontidae & & & & & & & & & & & & & & & & & & & & & & & & & \\
\hline Hydrolycus scomberoides & & & & & & & & & & & & & & & & 1 & + & + & 2 & 1 & & & & & \\
\hline Cynodon gibbus (juvenis) & 5 & + & + & + & 1 & & & & & & 4 & + & + & + & 1 & & & & & & & & & & \\
\hline Doradidae & & & & & & & & & & & & & & & & & & & & & & & & & \\
\hline Anduzedoras oxyrhynchus & 1 & + & + & + & 1 & & & & & & & & & & & & & & & & & & & & \\
\hline Astrodoras asterifrons & 7 & + & + & + & 2 & 5 & + & + & + & 3 & & & & & & & & & & & & & & & \\
\hline Hassar notospilus & & & & & & & & & & & & & & & & 1 & + & + & 1.2 & 1 & & & & & \\
\hline Hemidoras morrisi & 20 & 1 & 1 & 8.4 & 1 & 3 & + & + & 1 & 2 & & & & & & & & & & & & & & & \\
\hline Hemidoras stenopeltis & 46 & 2.3 & 2.3 & 21 & 6 & 37 & 2.8 & 2 & 10 & 4 & 1 & + & + & + & 1 & 15 & 2.2 & + & 6.4 & 1 & & & & & \\
\hline Leptodoras hesenani & & & & & & & & & & & & & & & & 3 & + & + & + & 2 & & & & & \\
\hline Leptodoras linnelli & 1 & + & + & 1.2 & 1 & 7 & + & + & 7 & 3 & & & & & & 16 & 2.3 & + & 29 & 5 & 7 & + & + & 14 & 3 \\
\hline Leptodoras praelongatus & 13 & + & + & 7.3 & 6 & 16 & 1.2 & + & 4.9 & 2 & 3 & + & + & 2.9 & 3 & 3 & + & + & 6 & 2 & 10 & + & + & 6.8 & 2 \\
\hline Nemadoras leporhinus & 27 & 1.3 & 1.3 & 13 & 6 & 9 & + & + & 2.7 & 4 & & & & & & 2 & + & + & 2 & 1 & & & & & \\
\hline Nemadoras trimaculatus & 21 & 1 & 1 & 3.1 & 3 & 11 & + & + & 1.8 & 3 & & & & & & 7 & 1 & + & 1.9 & 1 & & & & & \\
\hline Opsodoras stuebelii & 26 & 1.3 & 1.3 & 1.7 & 1 & 1 & + & + & + & 1 & & & & & & & & & & & & & & & \\
\hline Pterodoras cf. lentiginosus & 1 & + & + & + & 1 & & & & & & & & & & & & & & & & & & & & \\
\hline Rhyncodoras $\mathrm{sp} .1$ & & & & & & & & & & & & & & & & 1 & + & + & + & 1 & & & & & \\
\hline Stenodoras microstomus & 684 & 34 & 34 & 51 & 10 & 355 & 27 & 19 & 19 & 9 & 1 & + & + & + & 1 & 5 & + & + & + & 3 & & & & & \\
\hline Ageneiosidae & & & & & & & & & & & & & & & & & & & & & & & & & \\
\hline Ageneiosus sp. 2 & 3 & + & + & 10 & 1 & & & & & & & & & & & & & & & & & & & & \\
\hline Ageneiosus sp. 3 & 1 & + & + & 2.3 & 1 & & & & & & 1 & + & + & + & 1 & & & & & & & & & & \\
\hline Ageneiosus ucayalensis & 8 & + & + & 6.7 & 3 & & & & & & 1 & + & + & 4.2 & 1 & & & & & & & & & & \\
\hline Auchenipteridae & & & & & & & & & & & & & & & & & & & & & & & & & \\
\hline Auchenipterus nuchalis & 3 & + & + & + & 1 & & & & & & & & & & & & & & & & & & & & \\
\hline Centromochlus heckelii & & & & & & 1 & + & + & + & 1 & 21 & 4 & 1 & 6 & 1 & & & & & & & & & & \\
\hline $\begin{array}{l}\text { Pseudepapterus cucuhyensis } \\
\text { Pimelodidae }\end{array}$ & 1 & + & + & + & 1 & 6 & + & + & + & 1 & & & & & & & & & & & & & & & \\
\hline Brachyplatystoma filamentosum & 2 & + & + & 13 & 2 & & & & & & & & & & & & & & & & & & & & \\
\hline Calophysus macropterus & 2 & + & + & + & 2 & & & & & & & & & & & & & & & & & & & & \\
\hline Cheirocerus goeldii & 13 & + & + & 2.7 & 2 & 16 & 1.2 & + & 7.6 & 3 & 3 & + & + & 3 & 1 & 85 & 12 & 4.6 & 12 & 2 & & & & & \\
\hline Duopalatinus malarmo & 3 & + & + & 4 & 1 & & & & & & 1 & + & + & 2.5 & 1 & & & & & & 1 & + & + & 1.9 & 1 \\
\hline Duopalatinus peruanus & 1 & + & + & + & 1 & & & & & & & & & & & & & & & & & & & & \\
\hline Megalonema sp. n. & 4 & + & + & + & 3 & 27 & 2.1 & 1.4 & 2.2 & 4 & 1 & + & + & + & 1 & 46 & 6.7 & 2.5 & 6.4 & 5 & 40 & 3.5 & 1.8 & 4.4 & 8 \\
\hline Microglanis sp. 1 & & & & & & & & & & & & & & & & 1 & + & + & + & 1 & & & & & \\
\hline
\end{tabular}


Table 1. (cont.)

\begin{tabular}{|c|c|c|c|c|c|c|c|c|c|c|c|c|c|c|c|c|c|c|c|c|c|c|c|c|c|}
\hline & & & & & & & & Negr & & & & & & & & & & & & $\mathrm{oBr}$ & ranco & & & & \\
\hline & & & Sep & & & & & Nov & & & & & Feb & & & & & Sep & & & & & Feb & & \\
\hline & $\mathrm{N}$ & $\%$ & $\mathrm{D}$ & Bio & $\mathrm{F}$ & $\mathrm{N}$ & $\%$ & $\mathrm{D}$ & Bio & $\mathrm{F}$ & $\mathrm{N}$ & $\%$ & $\mathrm{D}$ & Bio & $\mathrm{F}$ & $\mathrm{N}$ & $\%$ & $\mathrm{D}$ & Bio & $\mathrm{F}$ & $\mathrm{N}$ & $\%$ & $\mathrm{D}$ & Bio & $\mathrm{F}$ \\
\hline Pimelodella cristata & 1 & + & + & + & 1 & 1 & + & + & + & 1 & 1 & + & + & + & 1 & 2 & + & + & + & 2 & & & & & \\
\hline Pimelodidae sp. n. 1 & 3 & + & + & + & 2 & 1 & + & + & + & 1 & & & & & & & & & & & & & & & \\
\hline Pimelodidae sp. n. 2 & 1 & + & + & + & 1 & & & & & & & & & & & & & & & & & & & & \\
\hline Pimelodidae sp. n. 3 & 19 & + & + & 1 & 4 & 18 & 1.4 & 1 & + & 4 & 35 & 6.6 & 1.6 & 2 & 1 & & & & & & & & & & \\
\hline Pimelodina flavipinnis & 2 & + & + & 14 & 1 & 3 & + & + & 5.5 & 2 & 2 & + & + & 15 & 1 & & & & & & 1 & + & + & 4.8 & 1 \\
\hline Pimelodus altipinnis & 15 & + & + & + & 3 & 23 & 1.8 & 1.2 & 6.4 & 4 & & & & & & 37 & 5.4 & 2 & 1.7 & 6 & 86 & 7.6 & $\begin{array}{ll}6 & 3.9\end{array}$ & 14 & 5 \\
\hline Pimelodus altissimus & 33 & 1.6 & 1.6 & 13 & 5 & 19 & 1.5 & 1 & 7.6 & 5 & & & & & & 19 & 2.8 & 1 & 12 & 2 & 2 & + & + & + & 1 \\
\hline Pimelodus blochii & 26 & 1.3 & 1.3 & 10 & 4 & 8 & + & + & 5.2 & 2 & 24 & 4.6 & 1.1 & 31 & 3 & 46 & 6.7 & 2.5 & 45 & 3 & 16 & 1.4 & $4+$ & 12 & 1 \\
\hline Pinirampus pirinampu & & & & & & & & & & & 1 & + & + & + & 1 & & & & & & & & & & \\
\hline $\begin{array}{l}\text { Platystomatichthys sturio } \\
\text { Cetopsidae }\end{array}$ & & & & & & 2 & + & + & 6.5 & 1 & & & & & & & & & & & 1 & + & + & 2.4 & 1 \\
\hline $\begin{array}{l}\text { Cetopsis sp. } \\
\text { Hypophthalmidae }\end{array}$ & 3 & + & + & + & 2 & & & & & & & & & & & & & & & & & & & & \\
\hline $\begin{array}{l}\text { Hypophthalmus cf. edentatus } \\
\text { Aspredinidae }\end{array}$ & 1 & + & + & 2.6 & 1 & & & & & & & & & & & & & & & & & & & & \\
\hline Acanthobunocephalus nicoi & & & & & & 1 & + & + & + & 1 & & & & & & & & & & & & & & & \\
\hline $\begin{array}{l}\text { Trichomycteridae } \\
\text { Stegophilus sp. } 4\end{array}$ & 1 & + & + & + & 1 & 2 & + & + & + & 1 & & & & & & & & & & & & & & & \\
\hline Loricariidae & & & & & & & & & & & & & & & & & & & & & & & & & \\
\hline Apistoloricaria sp. & 1 & + & + & + & 1 & & & & & & & & & & & & & & & & & & & & \\
\hline Furcodontichthys novaesi & 1 & + & + & + & 1 & 1 & + & + & + & 1 & & & & & & & & & & & & & & & \\
\hline Hypostomus micropunctatus & 2 & + & + & 4.7 & 1 & 1 & + & + & 3.1 & 1 & 1 & + & + & 1 & 1 & 1 & + & + & 1.7 & 1 & & & & & \\
\hline Limatulichthys punctatus & & & & & & 3 & + & + & + & 2 & 3 & + & + & + & 1 & 2 & + & + & + & 2 & 1 & + & + & + & 1 \\
\hline Loricaria cf. cataphracta & & & & & & 2 & + & + & 1.8 & 1 & 1 & + & + & 1.5 & 1 & 1 & + & + & + & 1 & 2 & + & + & + & 1 \\
\hline Loricaria sp. 1 & & & & & & 1 & + & + & + & 1 & & & & & & & & & & & 7 & + & + & + & 4 \\
\hline Loricaria sp. 2 & & & & & & 1 & + & + & + & 1 & & & & & & & & & & & & & & & \\
\hline Loricaria sp. "spiny" (new) & 2 & + & + & + & 1 & & & & & & & & & & & & & & & & & & & & \\
\hline Loricariichthys acutus & & & & & & & & & & & 1 & + & + & 1.8 & 1 & & & & & & 2 & + & + & + & 1 \\
\hline Loricariichthys nudirostris & & & & & & & & & & & 4 & + & + & 4.7 & 1 & & & & & & & & & & \\
\hline Pecklotia cf. vittata & & & & & & & & & & & 1 & + & + & + & 1 & & & & & & & & & & \\
\hline Pecklotia sp. 1 & & & & & & & & & & & & & & & & 1 & + & + & 1.6 & 1 & & & & & \\
\hline Pecklotia sp. 2 & & & & & & & & & & & & & & & & 1 & + & + & 1.1 & 1 & & & & & \\
\hline Pseudoloricaria of. laeviuscula & & & & & & 1 & + & + & 1.7 & 1 & & & & & & 1 & + & + & + & 1 & 1 & + & + & + & 1 \\
\hline Reganella depressa & 2 & + & + & + & 1 & 5 & + & + & + & 2 & 2 & + & + & + & 2 & 1 & + & + & + & 1 & 2 & + & + & + & 1 \\
\hline Rineloricaria aff. phoxocephala & & & & & & 1 & + & + & + & 1 & & & & & & & & & & & & & & & \\
\hline Spatuloricaria sp. & & & & & & & & & & & & & & & & & & & & & 1 & + & + & + & 1 \\
\hline Sturisoma sp. & 1 & + & + & + & 1 & & & & & & & & & & & & & & & & & & & & \\
\hline Sternopygidae & & & & & & & & & & & & & & & & & & & & & & & & & \\
\hline Distocyclus conirostris & 4 & + & + & 1.2 & 2 & & & & & & & & & & & & & & & & & & & & \\
\hline Eigenmannia macrops & 135 & 6.7 & 6.7 & 12 & 7 & 367 & 28 & 19 & 67 & 7 & 3 & + & + & + & 1 & 42 & 6.1 & 2.3 & 5.3 & 6 & 7 & + & + & + & 3 \\
\hline Eigenmannia virescens & 8 & + & + & 1.2 & 3 & 1 & + & + & + & 1 & & & & & & 3 & + & + & + & 1 & & & & & \\
\hline Rhabdolichops caviceps & 14 & + & + & 3.6 & 2 & & & & & & & & & & & 1 & + & + & + & 1 & & & & & \\
\hline Rhabdolichops eastwardi & 10 & + & + & 1 & 3 & & & & & & & & & & & 4 & + & + & + & 2 & & & & & \\
\hline Rhabdolichops electrogrammus & 11 & + & + & 1.6 & 3 & 13 & 1 & + & 2.6 & 4 & & & & & & 23 & 3.3 & 1.3 & 2 & 4 & & & & & \\
\hline Rhabdolichops troscheli & 1 & + & + & + & 1 & & & & & & & & & & & & & & & & & & & & \\
\hline Sternopygus macrurus & 1 & + & + & + & 1 & 1 & + & + & 3.2 & 1 & & & & & & & & & & & & & & & \\
\hline Rhamphichthyidae & & & & & & & & & & & & & & & & & & & & & & & & & \\
\hline Gymnorhamphichthys hypostomus & 2 & + & + & + & 1 & 1 & + & + & + & 1 & & & & & & & & & & & & & & & \\
\hline Gymnorhamphichthys sp. & & & & & & 1 & + & + & + & 1 & & & & & & & & & & & & & & & \\
\hline Rhamphichthys marmoratus & & & & & & & & & & & 1 & + & + & 4.1 & 1 & & & & & & 1 & + & + & 11 & 1 \\
\hline $\begin{array}{l}\text { Rhamphichthys sp. } 2 \\
\text { Hyponomidae }\end{array}$ & & & & & & & & & & & & & & & & 1 & + & + & 8.7 & 1 & & & & & \\
\hline Hypopomidae & & & & & & & & & & & & & & & & & & & & & & & & & \\
\hline $\begin{array}{l}\text { Steatogenys elegans } \\
\text { Apteronotidae }\end{array}$ & 40 & 2 & 2 & 6.8 & 6 & 25 & 1.9 & 1.3 & 4.5 & 5 & 2 & + & + & + & 2 & 1 & + & + & + & 1 & & & & & \\
\hline Adontosternarchus clarkae & 31 & 1.5 & 1.5 & 1.5 & 3 & & & & & & & & & & & & & & & & & & & & \\
\hline Adontosternarchus sachsi & 19 & + & + & 1.5 & 3 & & & & & & & & & & & & & & & & & & & & \\
\hline Adontosternarchus sp. (new) & 15 & + & + & + & 4 & 2 & + & + & + & 1 & & & & & & & & & & & & & & & \\
\hline Apteronotus bonapartii & 46 & 2.3 & 2.3 & 19 & 6 & 13 & 1 & + & 10 & 4 & 1 & + & + & + & 1 & & & & & & & & & & \\
\hline Magosternarchus duccis & & & & & & 1 & + & + & + & 1 & & & & & & & & & & & & & & & \\
\hline Orthosternarchus tamandua & 6 & + & + & 25 & 3 & & & & & & 1 & + & + & + & 1 & & & & & & & & & & \\
\hline Porotergus compsus & & & & & & 4 & + & + & 1.6 & 1 & 1 & + & + & + & 1 & & & & & & & & & & \\
\hline Porotergus sp. & 25 & 1.2 & 1.2 & 2.2 & 6 & 6 & + & + & + & 3 & & & & & & & & & & & & & & & \\
\hline Porotergus sp. 2 & 5 & + & + & + & 3 & & & & & & & & & & & 3 & + & + & + & 2 & & & & & \\
\hline Sternarchella schotti & 3 & + & + & 2.5 & 2 & 2 & + & + & 2 & 2 & & & & & & & & & & & & & & & \\
\hline Sternarchella terminalis & & & & & & 1 & & + & + & 1 & & & & & & & & & & & & & & & \\
\hline Sternarchogiton nattereri & 31 & 1.5 & 1.5 & 8.3 & 5 & 1 & + & + & + & 1 & & & & & & 5 & + & + & + & 1 & & & & & \\
\hline Sternarchogiton porcinum & 110 & 5.5 & 5.5 & 77 & 4 & 6 & + & + & 5.1 & 3 & & & & & & & & & & & & & & & \\
\hline Sternarchorhamphus muelleri & 3 & + & + & 1.2 & 1 & 1 & + & + & 1.3 & 1 & & & & & & 1 & + & + & 10 & 1 & & & & & \\
\hline Sternarchorhyncus oxyrhynchus & 17 & + & + & 7.1 & 2 & 2 & + & + & + & 2 & & & & & & & & & & & & & & & \\
\hline Sternarchorhyncus curvirostris & 2 & + & + & 1.8 & 1 & & & & & & & & & & & & & & & & & & & & \\
\hline $\begin{array}{l}\text { Sternarchorynchus sp. } 1 \\
\text { Scianidae }\end{array}$ & & & & & & 1 & + & + & + & 1 & & & & & & & & & & & & & & & \\
\hline Pachypops fourcroi & 1 & + & + & 2.4 & 1 & & & & & & 11 & 2.1 & + & + & 2 & & & & & & 20 & 1.8 & 31 & 2.5 & 4 \\
\hline Pachyurus schomburgkii & & & & & & 41 & 3.1 & 2.2 & 8.8 & 5 & 8 & 1.5 & + & 1.6 & 4 & 33 & 4.8 & 1.8 & 6.8 & 4 & 84 & 7.4 & 3.8 & 19 & 9 \\
\hline Pachyurus sp. A & 1 & + & + & + & 1 & 26 & 2 & 1.4 & 5 & 4 & 8 & 1.5 & + & 7.9 & 2 & & & & & & 10 & + & + & 3.9 & 3 \\
\hline Plagioscion sp. & 35 & 1.7 & 1.7 & 2 & 7 & 34 & 2.6 & 1.8 & 4.1 & 5 & 61 & 12 & 2.8 & + & 4 & 49 & 7.1 & 2.7 & 1 & 6 & 12 & 1.1 & $1+$ & 2.4 & 4 \\
\hline
\end{tabular}


Table 1. (cont.)

\begin{tabular}{|c|c|c|c|c|c|c|c|c|c|c|c|c|c|c|c|c|c|c|c|c|c|c|c|c|}
\hline & \multicolumn{14}{|c|}{ rio Negro } & \multicolumn{10}{|c|}{ rio Branco } \\
\hline & \multicolumn{4}{|c|}{ Sep } & \multicolumn{5}{|c|}{ Nov } & \multicolumn{5}{|c|}{ Feb } & \multicolumn{5}{|c|}{ Sep } & \multicolumn{5}{|c|}{ Feb } \\
\hline & $\mathrm{N} \quad \%$ & $\mathrm{D}$ & Bio & $\mathrm{F}$ & $\mathrm{N}$ & $\%$ & $\mathrm{D}$ & Bio & $\mathrm{F}$ & $\mathrm{N}$ & $\%$ & $\mathrm{D}$ & Bio & $\mathrm{F}$ & $\mathrm{N}$ & $\%$ & $\mathrm{D}$ & Bio & $\mathrm{F}$ & $\mathrm{N}$ & $\%$ & $\mathrm{D}$ & Bio & $\mathrm{F}$ \\
\hline \multicolumn{25}{|l|}{ Cichlidae } \\
\hline Acarichthys heckelli & & & & & 1 & + & + & + & 1 & & & & & & & & & & & & & & & \\
\hline Biotoecus opercularis & & & & & & & & & & 1 & + & + & + & 1 & & & & & & & & & & \\
\hline Crenicichla sp. 3 & & & & & & & & & & & & & & & 1 & + & + & + & 1 & & & & & \\
\hline Crenicichla sp. 4 & & & & & & & & & & 1 & + & + & + & 1 & & & & & & & & & & \\
\hline Geophagus sp. (new) & + & + & + & 1 & 53 & 4.1 & 2.8 & 8.8 & 5 & 116 & 22 & 5.4 & 20 & 5 & 14 & 2 & + & 9.2 & 2 & 88 & 7.8 & 4 & 12 & 8 \\
\hline \multicolumn{25}{|l|}{ Achiridae } \\
\hline Hypoclinemus mentalis & & & & & 1 & + & + & 1.2 & 1 & 1 & + & + & + & 1 & 2 & + & + & + & 1 & 1 & + & + & + & 1 \\
\hline \multicolumn{25}{|l|}{ Tetraodontidae } \\
\hline Colomesus asellus & & & & & & & & & & 1 & + & + & + & 1 & & & & & & & & & & \\
\hline Total & 2,007 & 100 & 395 & & 1,302 & & 69 & 235 & & 527 & & 24 & 120 & & 688 & & 38 & 204 & & 1,133 & & 52 & 150 & \\
\hline Number of Trawl & & & & & & & & & & & & & & & 11 & & & & & 12 & & & & \\
\hline Sample area $\left(\mathrm{m}^{2}\right)$ & 20,160 & & & & 18,900 & & & & & 21,60 & & & & & 18,36 & & & & & 21,96 & & & & \\
\hline Species caught & 92 & & & & 73 & & & & & 45 & & & & & 59 & & & & & 38 & & & & \\
\hline Biomass $(\mathrm{g})$ & 7,957 & & & & 4,440 & & & & & 2,594 & & & & & 3,749 & & & & & 3,284 & & & & \\
\hline
\end{tabular}

large catfishes during the drought period. According to local fishermen, these fish concentrate in that area to feed before moving upriver to spawn.

Other studies on stomach contents of large catfishes and cetaceans (Inia geoffrensis de Blainville and Sotalia fluviatilis Gervais \& Deville), frequently found benthic fishes ranging in size from 1.2 to $59 \mathrm{~cm}$ SL (Silva, 1983; Barthem \& Goulding, 1997). Benthic fishes collected in our trawls had the similar size range, from 1 to $58 \mathrm{~cm}$ SL.

Matthews (1998) indicated that during periods of drought, fish crowding may increase competition for food resources and increase predation pressures from both avian and aquatic predators. Vogt (2001) found fish bones of Doradidae; one of the most abundant benthic fish, in stomach contents of two species of turtles: Podocnemis erythrocephala Spix and Peltocephalus dumerilianus Schwigger. Large groups of cormorants, Phalocrocarax brasilianus Gmelin and other species of aquatic birds, are frequently seen on the rio Branco during low water periods. Sick (1984) reported that cormorant has a great ability to dive and capture benthic fish such as Pimelodus spp. Predation is a principal factor in the reductions of benthic fish densities during this study, a prolonged drought in a strong El Niño year.

Another hypothesis, which could explain the reduction in benthic fish densities during the study, would be the longitudinal migration of benthic fishes (J. G. Lundberg, pers. comm.). As mentioned earlier, during falling water benthic fish may migrate in search of refuge opportunities. However, the migration patterns of benthic fish are still not known.

No difference on abundance of the benthic fishes was found between strata depth $(<7 \mathrm{~m}$ and $>7 \mathrm{~m})$, but species compositions differed significantly. Greater species richness was found in the deepest stratum at the rio Negro site in September 1997, predominantly the Gymnotiformes and Silurifomes. Considering the general decline of the principal groups of benthic fishes, species richness between depth strata remained similar throughout the study period. At the rio Branco site in February 1998, we observed a tendency of increasing species richness at the deeper strata $(>7 \mathrm{~m})$. Fish may also seek refuge in deeper water to avoid predation from wading birds and diving cormorants during the period of higher water transparency (Secchi disc reading $>1 \mathrm{~m}$ ). Power (1987) also argued that fish tent to be found in deeper water to avoid wading/diving predators.

This study has shown that drought-related factors can affect the benthic fish communities of deeper channels in neotropical rivers. However, it is still not clearly understood whether such observed reductions occur annually or only during extremely prolonged dry period, which coincide with an El Niño event. Migration and predation are probably the two principal factors that reduce the abundance, species richness and change the composition of benthic fish assemblages. Increasing predation on benthic fishes during droughts may also play a significant role in the transfer of energy up the food chain, benefiting species at higher trophic levels.

\section{Acknowledgements}

To Jansen Zuanon, Bill Magnuson, Álvaro Carvalho and Bruce Marshall for revising drafts of the manuscript and Lucia Py-Daniel and John Lundberg for helping identify some Silurifomes and Gymnotiformes. Financial support of this study has been provided by CNPq - PNOPG (Process ${ }^{\circ}$. 520106/97-0 and 550367/2001-2 to NLC, P.I.), CNPq-PRONEX (466098/2001-4 to NLC, P.I.) and Bio-Amazonia Conservation International (USA) through Projeto Piaba. Many students and trainees at the Universidade Federal do Amazonas and Center of Aquatic Conservation (Projeto Piaba) in Barcelos have helped in field and laboratory work (Manuel Muniz, Cleuder Miranda Silva and Arnóbio Augusto). We also thank Scott Dowd of the New England Aquarium for organizing eco-tour excursions, which have provided us with boat rides to the study areas. In memoriam, we would like to give special remembrance to the kind efforts of Mr. Ramiro Fernandes (CPRM) who always helped with requests for river level data.

This study is from the thesis submitted to INPA/UFAM to partially fulfill the requirements of the Master of Science degree (MT-S). 


\section{Literature Cited}

Barletta, M. 1995. Estudos da comunidade de peixes bentônicos em três áreas do canal principal, próximas à confluência dos Rios Negros e Solimões - Amazonas (Amazônia Central Brasil). Unpublished M.S. Dissertation, INPA/UFAM, Manaus. 112 p.

Barthem, R. \& M. Goulding. 1997. Os bagres balizadores: ecologia, migração e conservação de peixes Amazônicos. Sociedade Civil Mamirauá. Brasília, CNPq, 130p.

Bayley, P. B., 1983. Central Amazon fish production: biomass, production and some dynamic characteristics. Unpublished Ph.D. Dissertation, Dalhouse University, 330p.

Belbin, L. 1992. PATN: Pattern Analysis Package. CSIRO, Canberra, Australia.

Bullock, T. H., N. Fernandes-Souza, W. Graf, W. Helligenberg, G. Langner, D. L. Meyer, F. Pimentel-Souza, H. Scheich \& T. A. Vialancour. 1979. Aspectos do uso de descarga do órgão elétrico e eletrorrecepção nos Gymnotoidei e outros peixes amazônicos. Acta Amazonica, 9(3): 549-572.

Chao, N. L., 2001. The Fishery, Diversity, and Conservation of Ornamental Fishes in the Rio Negro Basin, Brazil - A review of Project Piaba (1989-99). Pp. 161-204. In: N. L. Chao; P. Petry; G. Prang; L. Sonneschien and M. Tlusty (Eds.), Conservation and Management of Ornamental Fish Resouces of the Rio Negro Basin, Amazonia, Brazil-Projeto Piaba. Manaus, EDUA, 310p.

Cox-Fernands, C., 1995. Diversity, distribution and community structure of electric fishes (Gymnotiformes) in the channels of the Amazon River System, Brazil. Unpublished Ph.D. Dissertation, Duke University, 394 p.

Faith, D. P., P. R. Minchin \& L. Beldin. 1987. Compositional dissimilarity as a robust measure of ecological distance. Vegetatio 69: 57-68.

Garcia, M. 1995. Aspectos ecológicos dos peixes das águas abertas de um lago no Arquipélago das Anavilhanas, Rio Negro. Unpublished M.S. Dissertation, INPA/UFAM, Manaus, $94 \mathrm{p}$.

Goulding, M., 1980. The Fishes and the Forest: Explorations in Amazonian Natural History. Berkeley, University of California Press, 280p.

Goulding, M., M. L. Carvalho \& E. G. Ferreira. 1988. Rio Negro, rich life in poor water. The Hague, SPB Academic Publishing, 200p.

INPE. 1997. Boletim de Monitoramento e Análise Climática. Climanálise. 12(05-08-09).

Junk, W.J., G. M. Soares \& F. M. Carvalho. 1983. Distribution of fish species in a lake of the Amazon River floodplain near Manaus (Lago Camleão) with special reference to extreme oxygen conditions. Amazoniana, 7: 397-431.

Lake, P. S. 2003. Ecological effects of perturbation by drought in flowing water. Freshwater Biology, 48: 1161-1172.

Lopez-Rojas, H., J. G. Lundberg \& E. Marsh. 1984. Design and operation of a small trawling apparatus for use with dugout canoes. North American Journal of Fisheries Management. 4:331-334.
Lowe-McConnell, R. H. 1964. The fishes of the Rupununi savanna district of British Guiana. Journal of the Linnean Society (Zoological). London, 45: 103-144.

Lowe-McConnell, R. H. 1987. Ecological Studies in Tropical Fish Communities. Cambridge, Cambridge Tropical Biology Series 382p.

Lundberg, J. G., W. M. Lewis, J. F. Saunders \& F. Magio-Leccia. 1987. A major food web component in the Orinoco river channel: evidence from planktivorous eletric fishes. Science 237: 81-83.

Magoulick, D. D. \& R. M. Kobza. 2003. The role of refugia for fishes during drought: a review and synthesis. Freshwater Biology, 48: 1186-1198.

Matthews, W. J. 1998. Patterns in freshwater ecology. New York, Chapman \& Hall, 756p.

Olson, C. L. 1976. On choosing a test satistic in multivariate analysis of variance. Psychological Bulletin 83: 579-586.

Power, M. E. 1987. Predator avoidance by grazing stream fishes in temperate and tropical streams: Importance of stream depth and prey size. Pp. 333-351. In: Kerfoot, W. C. and Sih, A. (Eds), Predation: Direct and Indirect Impacts in Aquatic Communities. University Press of New England, Hanover, NH. 394p.

Sanders, H. L. 1968. Marine benthic diversity: a comparative study. American Naturalist, 102: 243-282.

Sick, H. 1984. Ornitologia brasileira. UNB - $3^{\text {a }}$ edição. Brasília. 1 e 2 Vol: 810p.

Silva, V.M.F. 1983. Ecologia alimentar dos golfinhos da Amazônia. Unpublished M.S. Dissertation, INPA/UFAM, Manaus. 112 p.

Sioli, H. 1991. Amazônia. Fundamentos da ecologia da maior região de florestas tropicais. Tradução de Johann Becker. $3^{\mathrm{a}}$ edição. Petrópolis, Rio de Janeiro. Editora Vozes Ltda. 72 p.

Sparre, P., E. Ursin \& S. C. Vinema. 1997. Introduction to tropical fish stock assessment. Rome, F.A.O, 404p.

Steinbach, A. B. 1970. Diurnal movements and discharge characteristics of electric Gymnotid fishes in the Rio Negro, Brazil. The Biological Bulletin. 138: 200-210.

Vogt, R. C. 2001. Turtles of the Rio Negro. Pp. 245-262. In: N. L. Chao; P. Petry; G. Prang; L. Sonneschien and M. Tlusty (Eds). Conservation and Management of Ornamental Fish Resouces of the Rio Negro Basin, Amazonia, Brazil-Projeto Piaba. Manaus, EDUA, 310p.

Winemiller, K. O. 1996. Dynamic diversity in fish assemblages of tropical rivers. Pp. 99-134. In: M. L. Cody and J. A. Smallwood (Eds), Long Term Studies of Vertebrate Communities. San Diego, Academic Pess, Inc., 597p.

Winemiller, K. O. \& D. P. Jepsen. 1998. Effects of seasonality and fish movements on tropical river food webs. Journal of Fish Biology, 53: 267-296.

Zar, J. H. 1984. Bioestatistical analysis, $2^{\text {nd }}$ edition. Englewood Cliffs, Princeton-Hall, 718p.

Zuanon, J. A. S. 1990. Aspectos da biologia, ecologia e pesca de grandes bagres (Pisces: Siluriformes, Siluroidei) na área da ilha da Marchantaria - Rio Solimões, AM. Unpublished M.S. Dissertation, INPA/UFAM, Manaus. 185 p.

Received December 2003 Accepted August 2004 